\title{
Prototype System Water Level Reservoir untuk Pengendalian Kelebihan Air dengan Mikrokontroller Arduino Uno R3
}

\author{
Budi Yannur ${ }^{1}$, Didit Suprihanto*2, Happy Nugroho ${ }^{3}$, Aji Ery Burhandenny ${ }^{4}$, Restu \\ Mukti Utomo 5 \\ 1,2,3,4,5 Program Studi Teknik Elektro, Universitas Mulawarman \\ budiannur2018@gmail.com ${ }^{1}$, didit.suprihanto@ft.unmul.ac.id ${ }^{* 2}$, \\ happynugroho@ft.unmul.ac.id ${ }^{3}$, a.burhandenny@ft.unmul.ac.id ${ }^{4}$, \\ restuutomo@ft.unmul.ac.id ${ }^{5}$
}

(Received: 30 Oktober 2021 / Accepted: 23 November 2021 / Published Online: 20 Desember 2021)

\begin{abstract}
Abstrak
PDAM Cabang Loa Kulu masih menggunakan tongkat atau galah sebagai indikator ketinggian air di dalam reservoir. Reservoir adalah tempat penampungan hasil produksi air bersih dari PDAM, kelemahan dengan menggunakan tongkat atau galah adalah ketika operator tidak memonitoring secara terus-menerus menyebabkan kehilangan air saat produksi menjadi besar. Tujuan penelitian ini adalah merancang bangun prototype water level untuk mengendalikan kelebihan air di dalam reservoir. Metode yang digunakan adalah prototype dengan tahapan pengumpulan informasi melalui mewawancarai staf PDAM, membuat dan memperbaiki prototype dan menguji coba prototype. Pengujian ini menggunakan perangkat keras yang terdiri dari arduino uno r3, sensor ultrasonic hc-sr04, sensor flowmeter yf-s201, lcd $16 \times 2$, modul relay, buzzer, solenoid valve $12 V_{d c}$, pompa $12 V_{d c}$ dan menampilkan hasil pengukuran pada aplikasi visual studio 2019. Hasil temuan kami adalah lama pengisian reservoir dengan debit input rata-rata 3,6 liter/menit adalah 2,93 menit. Sedangkan untuk lama pengosongan reservoir dengan debit output rata-rata 1,06 liter/menit adalah 12,10 menit. Kesimpulan hasil penelitian ini adalah sistem dapat memonitoring ketinggian air di dalam reservoir secara otomatis dan mengetahui waktu yang dibutuhkan untuk proses pengisian dan pengosongan reservoir.
\end{abstract}

Kata kunci: Flowmeter, Reservoir, Sensor, Ultrasonic, Water level.

\begin{abstract}
PDAM Loa Kulu Branch still uses sticks or poles as an indicator of the water level in the reservoir. Reservoir is a place to store clean water production from PDAM, the weakness of using sticks or poles is when the operator does not monitor continuously causing air loss when production becomes large. The goal of the study was to design a water-level prototype to control excess water in the reservoir. The method used is a prototype with the stage of gathering information through interviewing PDAM staff, creating and repairing prototypes and testing prototypes. The test used hardware consisting of arduino uno r3, ultrasonic sensor hc-sr04, flowmeter sensor yf-s201, $16 \times 2$ lcd, relay module, buzzer, solenoid valve $12 \mathrm{~V} \_d c$, pump $12 \mathrm{~V} \_d c$ and display measurement results in the visual studio application 2019. Our findings are that the length of reservoir charging with an average input discharge of 3.6 liters / minute is 2.93 minutes. As for the length of emptying the reservoir with an average output discharge of 1.06 liters / minute is 12.10 minutes. The conclusion of this study is that the system can monitor the water level inside the reservoir automatically and know the time needed for the feeling and emptying process of the reservoir.
\end{abstract}

Keywords: Flowmeter, Reservoir, Sensor, Ultrasonic, Water level. 


\section{PENDAHULUAN}

Air merupakan kebutuhan pokok yang harus dipenuhi terutama di perkotaan yang padat penduduk. Selain untuk konsumsi air juga digunakan untuk hal lain, seperti mandi, mencuci, industri, pertanian dan lain-lain(Triono, 2018). Menurut (Suratmi, 2017) dalam rangka memenuhi kebutuhan air bersih yang semakin meningkat, selain itu masih rendahnya prosentase cakupan pelayanan air bersih yaitu sebesar 53,1\% (data Bagian Hubungan Langganan PDAM Tirta Mahakam) di wilayah pelayanan PDAM Cabang Loa Kulu. Cakupan pelayanan tersebut jauh dari ketentuan yang belaku yaitu sebesar 90\%. Untuk itu perlu peninjauan kembali kebutuhan air bersih untuk wilayah pelayanan PDAM Cabang Loa Kulu Kecamatan Loa Kulu pada saat sekarang dan masa yang akan datang, agar kebutuhan masyarakat wilayah pelayanan PDAM Loa Kulu akan air bersih dapat terpenuhi.

Perusahaan Daerah Air Minum (PDAM) adalah badan usaha milik pemerintah (Haiqal et al., 2021) yang bergerak dalam bidang distribusi air bersih bagi masyarakat umum. Pada PDAM Cabang Loa Kulu memiliki 2 reservoir. Reservoir adalah tempat untuk menampung hasil produksi air bersih. Dalam proses produksi air bersih di PDAM Cabang Loa Kulu sering terjadi kelebihan air pada reservoir karna untuk monitoringnya masih menggunakan tenaga manusia atau dengan menggunakan galah sebagai indikator ketinggian air. Hal ini menyebabkan terbuang secara percuma air bersih yang telah diproduksi.

Mikrokontroller adalah sebuah komputer kecil di dalam satu IC yang berisi CPU, memori, timer, saluran komunikasi serial dan parallel, port input/output, ADC (Suhaeb et al., 2017) atau mikrokontroler dapat disebut sebagai komputer dalam sebuah chip (Akinwole, 2020) Mikrokontroller dapat menerima sinyal input, mengolahnya dan memberikan sinyal output sesuai dengan program yang diisikan di dalamnya (Destiarini, 2020). Pada penelitian ini menggunakan arduino uno r3, yaitu sebuah board mikrokontroller yang berbasis pada ATmega328 (Irvawansyah \& Azis, 2018) dan arduino uno r3 digunakan sebagai perangkat pengendali (Haszerila et al., 2019). Bahasa program yang digunakan pada mikrokontroller arduino uno $\mathrm{r} 3$ adalah bahasa $\mathrm{C}$, yaitu bahasa yang menerapkan konsep runtutan dimana program dieksekusi per baris dari atas ke bawah secara berurutan (Zakaria et al., 2021). Struktur dasar dalam pemrograman arduino terdiri atas dua bagian, yaitu fungsi persiapan $(\operatorname{setup}())$ dan fungsi utama (loop()) (Destiarini, 2020).

Flowmeter adalah alat untuk mengukur jumlah atau laju aliran volumetrik cairan atau gas dari suatu fluida yang mengalir dalam suatu pipa atau terbuka (Pelawi, \& Manan, 2017). Penggunaan sensor flowmeter yf-s201 untuk mengetahui debit air yang mengalir sedangkan ketinggian air di dalam reservoir dapat diukur dengan sensor ultrasonic hc-sr04. Pembangunan prototype membutuhkan power supply sebagai suplai daya untuk mensuplai arus listrik DC (Direct Current) ke prototype yang dibangun, menurut (Sitohang et al., 2018) catu daya (power supply) adalah sebuah perangkat yang memasok listrik energi untuk satu atau lebih beban listrik. Catu daya menjadi bagian yang penting dalam elektonika yang berfungsi sebagai sumber tenaga listrik misalnya pada baterai atau accu. Kemudian data pengukuran dapat ditampilkan melalui LCD 16 × 2. LCD 16 x 2 merupakan media yang digunakan untuk menampilkan hasil dari keluaran sebuah rangkaian elektronika (Amarudin et al., 2020). Selain itu data dapat ditampilkan melalui aplikasi visual studio 2019.

Penelitian dari (Alawiah \& Al Tahtawi, 2017) telah berhasil dibuat alat kendali dan monitoring ketinggian air. Sensor ultrasonic merupakan suatu perangkat yang dapat mengukur jarak suatu objek dengan memanfaatkan pantulan gelombang ultrasonic. Sensor ultrasonic adalah sebuah sensor yang berfungsi mengubah besaran fisis (bunyi) menjadi besaran listrik atau sebaliknya (Gunawan et al., 2020). Sistem kendali dirancang menggunakan relay sebagai saklar yang diatur oleh mikrokontroller dengan metode kendali histerisis. Relay adalah Saklar (Switch) yang dioperasikan secara listrik (Saleh \& Haryanti, 2017). Sedangkan penelitian dari (Amin, 2018) telah dibuat suatu alat yang dapat melakukan monitoring ketinggian permukaan 
air secara otomatis. Prinsip kerja alat adalah apabila bak penampungan air dalam kondisi kosong atau mencapai level low, maka sensor ultrasonic hc-sr04 akan mendeteksi ketinggian air dan memberikan sinyal ke arduino uno untuk menghidupkan pompa pengisi bak penampungan air dan mengirimkan data ketinggian air pada LCD. Apabila bak penampungan air dalam keadaan penuh atau mencapai level high, maka sensor ultrasonic hc-sr04 akan mendeteksi ketinggian air dan memberikan sinyal ke arduino uno untuk mematikan pompa pengisi bak penampungan air secara otomatis dan mengirimkan data ketinggian air pada LCD, sehingga memudahkan dalam pengontrolan persediaan air. Beberapa penelitian tersebut hanya menghidupkan dan mematikan pompa secara otomatis berdasarkan setpoint yang ditetapkan, oleh karena itu dalam penelitian ini selain menghidupkan dan mematikan pompa secara otomatis maka dapat juga diketahui waktu yang dibutuhkan untuk proses pengisian dan pengosongannya.

Berdasarkan hal tersebut di atas, maka tujuan penelitian ini adalah merancang bangun prototype alat untuk mengetahui kinerja sistem otomatis yang dapat mengukur ketinggian air pada reservoir dan mengetahui waktu yang dibutuhkan untuk proses pengisian dan pengosongan reservoir.

\section{METODE}

Metode dalam merancang dan membuat sistem pengaturan monitoring ketinggian air pada reservoir menggunakan sensor ultrasonic hc-sr04 dan sensor flowmeter yf-s201 berbasis mikrokontroller arduino uno r3 yaitu metode prototype. Prototype merupakan suatu metode dalam pengembangan sistem yang menggunakan pendekatan untuk membuat sesuatu program dengan cepat dan bertahap sehingga dapat di evaluasi oleh pengguna (Gunawan \& Fatimah, 2020; Hidayat et al., 2020; Michael \& Gustina, 2019). Pada metode prototype terdapat beberapa tahapan meliputi: yang pertama yaitu mewawancarai secara langsung Staf PDAM. Pada tahap ini kami meminta data dan informasi mengenai permasalahan sistem yang berjalan pada reservoir PDAM dan mencari studi literatur sebagai penunjang pada sistem. Langkah kedua merancang dan membuat prototype. Tahap ini dilakukan perancangan dan pembuatan prototype sistem. Prototype yang dibuat disesuaikan dengan kebutuhan sistem yang telah didefinisikan sebelumnya dari keluhan staf PDAM. Langkah ketiga yaitu uji coba. Pada tahap ini staf PDAM menguji coba sistem yang sudah dibuat dan dibangun kemudian dilakukan evaluasi kekurangan-kekurangan dari kebutuhan staf PDAM.

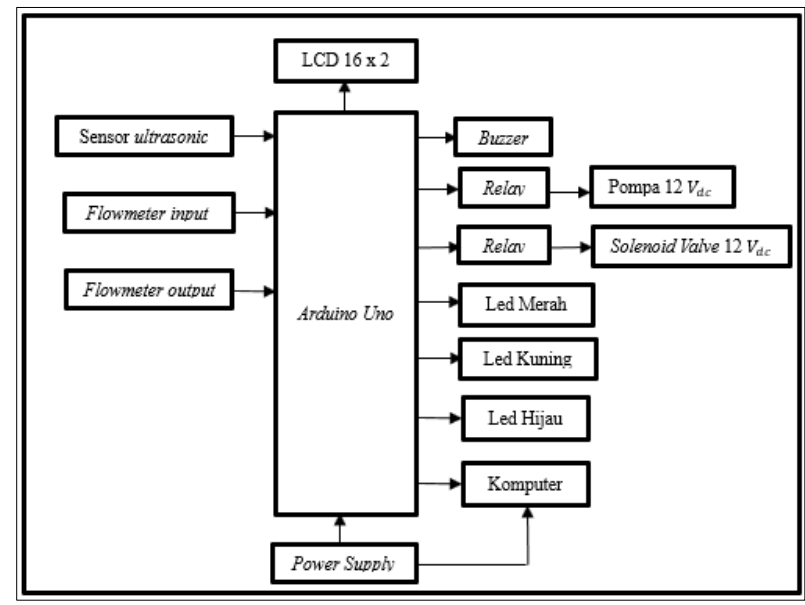

Gambar 1. Diagram Blok Sistem

Pada tahap perancangan sistem dijelaskan tentang implementasi sistem pengaturan monitoring ketinggian air pada reservoir menggunakan sensor ultrasonic hc-sr04 dan sensor flowmeter yf-s201 berbasis mikrokontroller arduino uno r3, perancangan pada penelitian ini dibagi menjadi dua proses yaitu meliputi proses perancangan perangkat keras (hardware) dan 
perancangan perangkat lunak (software). Pada gambar 1 perancangan perangkat keras yang dibangun menggunakan mikrokontroller arduino uno r3 sebagai pengendali, sensor ultrasonic hc-sr04 sebagai pembaca ketinggian air di dalam reservoir, 2 buah sensor flowmeter yf-s201 untuk mengetahui debit air yang masuk dan keluar di dalam reservoir, layar lcd 16 x 2 untuk menampilkan pembacaan ketinggian air, pompa $12 V_{d c}$, solenoid valve, buzzer sebagai peringatan ketika air sudah penuh, relay sebagai on/off pompa $12 V_{d c}$ dan relay sebagai on/off solenoid valve, 3 buah lampu led sebagai indikator ketinggian air.

Perancangan perangkat lunak dari sistem berdasarkan gambar 1, yang pertama mikrokontroler melakukan inisialisasi pin I/O. Proses kedua adalah inisialisasi komunikasi serial. Proses ketiga adalah menghubungkan port arduino uno dengan aplikasi visual studio 2019. Setelah komputer dapat mengakses port arduino uno melalui aplikasi visual studio 2019 maka program dilanjutkan dengan membaca nilai sensor ultrasonic hc-sr04 dan sensor flowmeter yf-s201. Tekan tombol set level air untuk mengatur keluaran nilai dari relay, buzzer, dan lampu led. Jika level air lebih kecil atau sama dengan nilai low yaitu $10 \mathrm{~cm}$, maka led hijau on, relay pompa $12 V_{d c}$ on, relay solenoid valve on, dan buzzer off. Jika level air lebih kecil atau sama dengan nilai medium yaitu $20 \mathrm{~cm}$, maka led kuning on, relay pompa $12 V_{d c}$ on, relay solenoid valve on dan buzzer off. Jika level air lebih besar atau sama dengan $21 \mathrm{~cm}$, maka maka led merah on, relay pompa $12 V_{d c}$ on, relay solenoid valve on dan buzzer off. Jika level air lebih besar atau sama dengan nilai high yaitu $30 \mathrm{~cm}$, maka led merah on, relay pompa $12 V_{d c}$ off, relay solenoid valve off dan buzzer on. Hasil pembacaan nilai dari sensor ultrasonic hc-sr04 dan sensor flowmeter yf-s201 akan ditampilkan pada LCD 16 × 2 dan komputer pada aplikasi visual studio 2019.

Reservoir yang digunakan dalam penelitian ini berbentuk tabung, Menurut (Saputra et al., 2016) untuk mengetahui volume atau pun isi dari sebuah tabung maka harus mengetahui jari - jari atau pun diameter dari penampang (alas/tutup) tabung tersebut. Dapat dirumuskan pada persamaan 1 sebagai berikut.

$$
v=\pi \cdot r^{2} \cdot T
$$

Selanjutnya menurut (Setyadi \& Nurcahyo, 2017) untuk mencari nilai waktu yang dibutuhkan untuk mengisi tabung dapat menggunakan persamaan 2 dibawah ini.

$$
t=\frac{v}{d}
$$

\section{HASIL DAN PEMBAHASAN}

Hasil

Penampungan filter air yang dibangun pada penelitian ini terbuat dari bahan plastik bening yang berbentuk persegi panjang dengan ukuran panjang $30 \mathrm{~cm}$, tinggi $19,5 \mathrm{~cm}$ dan lebar $19,5 \mathrm{~cm}$ dengan volume total $11,407,5 \mathrm{~cm}^{3}$. Untuk lebih jelasnya dapat dilihat pada gambar 2 .

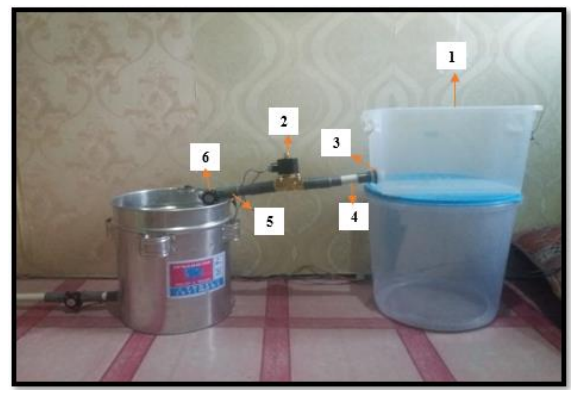

Gambar 2. Pembangunan Penampungan Filter Air 
Keterangan:
1. Filter Air
3. Nepel drat $1 / 2$ inch
2. Solenoid valve $12 V_{d c}$
5. Sock drat dalam $1 / 2$ inch
4. Pipa $1 / 2$ inch
6. Sensor flowmeter yf-s201

Reservoir yang dibangun pada penelitian ini terbuat dari bahan seng yang berbentuk tabung dengan diameter $28 \mathrm{~cm}$ dan tinggi $32 \mathrm{~cm}$ dengan volume total 19,694,08 $\mathrm{cm}^{3}$. Untuk lebih jelasnya dapat dilihat pada gambar 3 .

Keterangan:

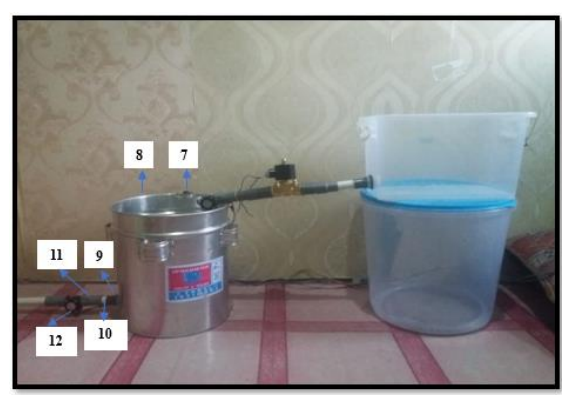

1. Sensor ultrasonic hc-sr04

2. Reservoir

3. Nepel drat $1 / 2$ inch

4. Pipa $1 / 2$ inch

5. Sock drat dalam $1 / 2$ inch

6. Sensor flowmeter yf-s201

Hasil pengujian lama pengisian reservoir pada tabel 1 merupakan pengujian yang dilakukan untuk mengetahui waktu yang dibutuhkan dalam proses mengisi reservoir hingga penuh. Pada tabel 1 pengukuran ketinggian air menggunakan sensor ultrasonic hc-sr04 dan sensor flowmeter yf-s201 untuk debit input air.

Tabel 1. Pengujian Lama Pengisian Reservoir

\begin{tabular}{ccccc}
\hline No & $\begin{array}{c}\text { Pengukuran } \\
\text { Sensor Ultrasonic } \\
(\boldsymbol{c m})\end{array}$ & $\begin{array}{c}\text { Volume Isi } \\
\text { Reservoir }\left(\mathbf{c m}^{\mathbf{3}}\right)\end{array}$ & $\begin{array}{c}\text { Debit Input Air } \\
\text { (liter/menit })\end{array}$ & $\begin{array}{c}\text { Lama } \\
\text { Pengisian } \\
(\text { menit })\end{array}$ \\
\hline $\mathbf{1}$ & 2 & 1709 & 4 & 5,98 \\
$\mathbf{2}$ & 5 & 4274 & 3 & 7,12 \\
$\mathbf{3}$ & 7 & 5984 & 4 & 4,92 \\
$\mathbf{4}$ & 9 & 7693 & 4 & 4,49 \\
$\mathbf{5}$ & 11 & 9403 & 4 & 4,06 \\
$\mathbf{6}$ & 13 & 11113 & 4 & 3,63 \\
$\mathbf{7}$ & 15 & 12822 & 4 & 3,21 \\
$\mathbf{8}$ & 17 & 16242 & 4 & 2,78 \\
$\mathbf{9}$ & 19 & 17952 & 4 & 2,35 \\
$\mathbf{1 0}$ & 21 & 19661 & 4 & 1,92 \\
$\mathbf{1 1}$ & 23 & 21371 & 4 & 1,50 \\
$\mathbf{1 2}$ & 25 & 23081 & 4 & 1,07 \\
$\mathbf{1 3}$ & 27 & 24791 & 4 & 0,64 \\
$\mathbf{1 4}$ & 29 & 25645 & 3 & 0,28 \\
$\mathbf{1 5}$ & 30 & & 3 & 0 \\
& Rata Rata & & $\mathbf{3 , 6}$ & $\mathbf{2 , 9 3}$ \\
\hline
\end{tabular}


Perhitungan lama pengisian reservoir pada jarak $5 \mathrm{~cm}$.

$\left(T_{\text {kos }}=30-5=25 \mathrm{~cm}\right)$

mencari volume kosong $\left(\mathrm{V}_{\mathrm{kos}}\right)$ tabung:

Mencari tinggi kosong tabung

$$
V_{k o s}=\pi \cdot r^{2} \cdot T_{k o s}
$$

Mencari waktu lama pengisian reservoir

$$
\mathrm{T}_{\mathrm{kos}}=\mathrm{T}_{\mathrm{tab}}-\mathrm{T}_{\mathrm{isi}}
$$

$$
\begin{aligned}
t & =\frac{T_{k o s} \cdot \pi \cdot r^{2}}{d_{i n}} \\
t & =\frac{25 \mathrm{~cm} \times 3,14 \times 16,5^{2} \mathrm{~cm}}{3000 \mathrm{ml}} \\
t & =\frac{21,371,62 \mathrm{~cm}^{3}}{3000 \mathrm{ml}}=7,12 \text { menit }
\end{aligned}
$$

Dimana:

$\mathrm{T}_{\mathrm{kos}}=$ Tinggi kosong tabung yang belum terisi

$\mathrm{T}_{\text {tab}}=$ Batas Tinggi permukaan air tabung dalam keadaan penuh $(30 \mathrm{~cm})$

$\mathrm{T}_{\text {isi }}=$ Tinggi permukaan air yang telah terisi dalam tabung

$\mathrm{d}_{\mathrm{in}}=$ debit input air

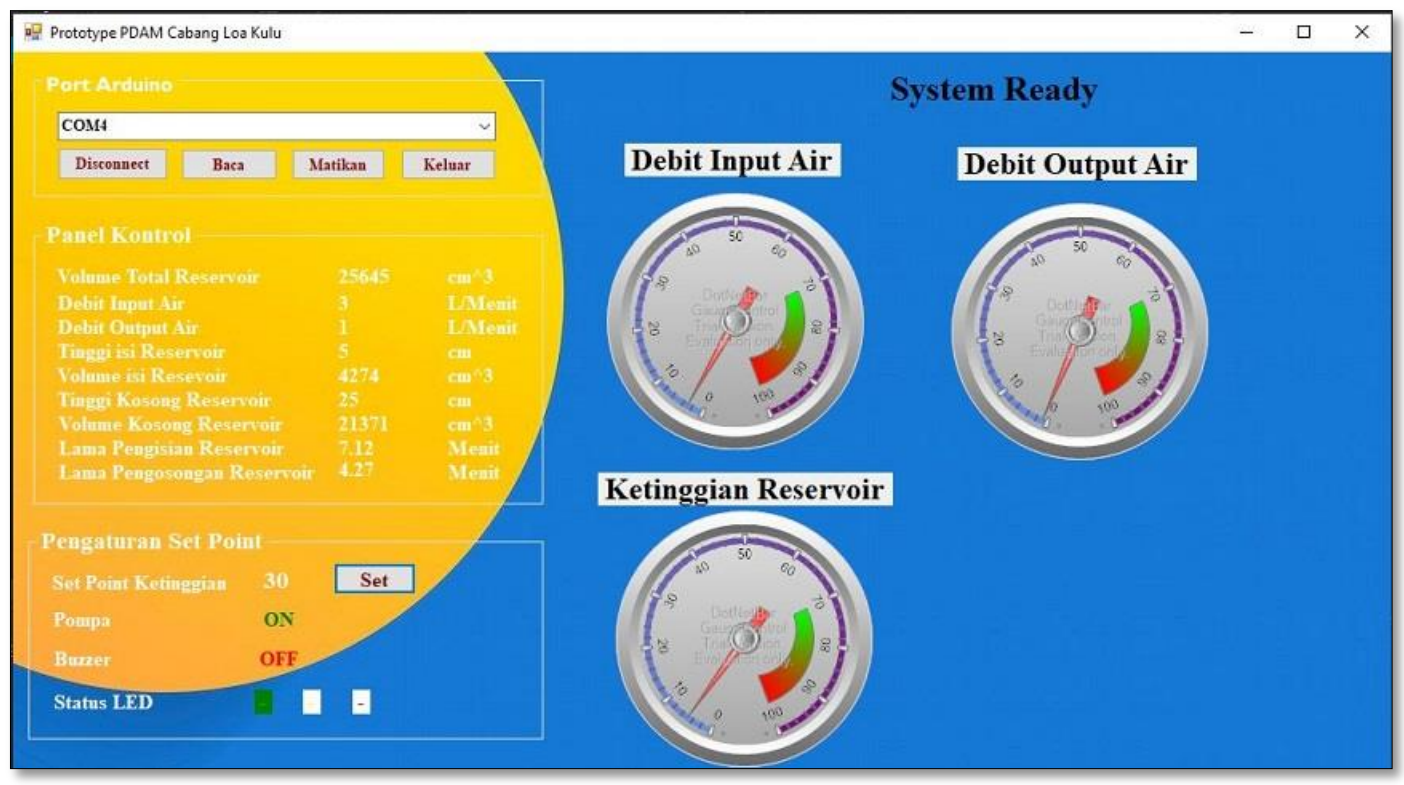

Gambar 4. Tampilan Hasil Pengujian Lama Pengisian Reservoir pada Jarak $5 \mathrm{~cm}$

Adapun tampilan hasil pengujian dapat dilihat pada gambar 4. Pada gambar tersebut menunjukkan port arduino terhubung dengan aplikasi visual studio 2019 melalui COM4. Pada menu kontrol panel terdapat volume total reservoir merupakan volume keseluruhan dari reservoir yang digunakan, debit input air merupakan debit air yang masuk dari filter air ke reservoir, debit output air merupakan debit air yang keluar dari reservoir, tinggi isi reservoir merupakan ketinggian air didalam reservoir, volume isi reservoir merupakan volume reservoir yang telah terisi air, tinggi kosong reservoir merupakan ketinggian reservoir yang belum terisi oleh air, volume kosong reservoir merupakan volume reservoir yang belum terisi oleh air, lama pengisian reservoir merupakan waktu yang dibutuhkan untuk mengisi reservoir hingga penuh dan lama pengosongan reservoir merupakan waktu yang dibutuhkan untuk mengosongkan reservoir. Menu pengaturan setpoint terdapat setpoint ketinggian untuk mengatur setpoint ketinggian air, status pompa on atau off, status buzzer on atau off, dan status lampu led dengan warna sesuai ketinggian air. 
Hasil Pengujian lama pengosongan reservoir pada tabel 2 merupakan pengujian yang dilakukan untuk mengetahui waktu yang dibutuhkan dalam proses mengosongkan reservoir hingga penuh. Pada tabel 2 pengukuran ketinggian air menggunakan sensor ultrasonic hc-sr04 dan sensor flowmeter yf-s201 untuk debit output air.

Tabel 2. Pengujian Lama Pengosongan Reservoir

\begin{tabular}{ccccc}
\hline No & $\begin{array}{c}\text { Pengukuran } \\
\text { Sensor Ultrasonic } \\
(\mathbf{c m})\end{array}$ & $\begin{array}{c}\text { Volume Kosong } \\
\text { Reservoir }\left(\mathbf{c m}^{\mathbf{3}}\right)\end{array}$ & $\begin{array}{c}\text { Debit } \\
\text { Output } \text { Air } \\
(\text { l/menit })\end{array}$ & $\begin{array}{c}\text { Lama } \\
\text { Pengosongan } \\
(\text { menit })\end{array}$ \\
\hline $\mathbf{1}$ & 30 & 0 & 1 & 25,65 \\
$\mathbf{2}$ & 29 & 854 & 2 & 12,40 \\
$\mathbf{3}$ & 27 & 2564 & 1 & 23,08 \\
$\mathbf{4}$ & 25 & 4274 & 2 & 10,69 \\
$\mathbf{5}$ & 23 & 5984 & 2 & 9,83 \\
$\mathbf{6}$ & 21 & 7693 & 1 & 17,95 \\
$\mathbf{7}$ & 19 & 9403 & 1 & 16,24 \\
$\mathbf{8}$ & 17 & 11113 & 1 & 14,53 \\
$\mathbf{9}$ & 15 & 12822 & 1 & 12,82 \\
$\mathbf{1 0}$ & 13 & 14532 & 1 & 11,11 \\
$\mathbf{1 1}$ & 11 & 16242 & 1 & 9,40 \\
$\mathbf{1 2}$ & 9 & 17952 & 1 & 7,69 \\
$\mathbf{1 3}$ & 7 & 19661 & 1 & 5,98 \\
$\mathbf{1 4}$ & 5 & 21371 & 1 & 4,27 \\
$\mathbf{1 5}$ & 2 & 23936 & 0 & 0 \\
& & & $\mathbf{1 , 0 6}$ & $\mathbf{1 2 , 1 0}$ \\
\hline
\end{tabular}

Perhitungan lama pengosongan reservoir pada jarak $5 \mathrm{~cm}$.

$\left(T_{i s i}=30-25=5 \mathrm{~cm}\right)$

mencari volume isi $\left(\mathrm{V}_{\text {isi }}\right)$ tabung:

Mencari tinggi isi tabung

$$
V_{i s i}=\pi \cdot r^{2} \cdot T_{i s i}
$$

$$
\mathrm{T}_{\mathrm{isi}}=\mathrm{T}_{\mathrm{tab}}-\mathrm{T}_{\mathrm{kos}}
$$

Mencari waktu lama pengisian reservoir

$t=\frac{T_{i s i} \cdot \pi \cdot r^{2}}{d_{\text {out }}}$

$t=\frac{5 \mathrm{~cm} \times 3,14 \times 16,5 \mathrm{~cm}^{2}}{1000 \mathrm{ml}}$

$t=\frac{4,274,32 \mathrm{~cm} 3}{1000 \mathrm{ml}}=4,27$ menit

Dimana:

$\mathrm{T}_{\text {isi }}=$ Tinggi permukaan air yang telah terisi dalam tabung

$\mathrm{T}_{\mathrm{kos}}=$ Tinggi kosong tabung yang belum terisi

$\mathrm{T}_{\text {tab }}=$ Batas Tinggi permukaan air tabung dalam keadaan penuh $(30 \mathrm{~cm})$

$\mathrm{D}_{\text {out }}=$ debit output air

Adapun tampilan hasil pengujian dapat dilihat pada gambar 5. Pada gambar tersebut port arduino terhubung dengan aplikasi visual studio 2019 melalui COM4. Pada menu kontrol panel terdapat volume total reservoir merupakan volume keseluruhan dari reservoir yang digunakan, debit input air merupakan debit air yang masuk dari filter air ke reservoir, debit output air 
merupakan debit air yang keluar dari reservoir, tinggi isi reservoir merupakan ketinggian air didalam reservoir, volume isi reservoir merupakan volume reservoir yang telah terisi air, tinggi kosong reservoir merupakan ketinggian reservoir yang belum terisi oleh air, volume kosong reservoir merupakan volume reservoir yang belum terisi oleh air, lama pengisian reservoir merupakan waktu yang dibutuhkan untuk mengisi reservoir hingga penuh dan lama pengosongan reservoir merupakan waktu yang dibutuhkan untuk mengosongkan reservoir. Menu pengaturan setpoint terdapat setpoint ketinggian untuk mengatur setpoint ketinggian air, status pompa on atau off, status buzzer on atau off, dan status lampu led dengan warna sesuai ketinggian air.

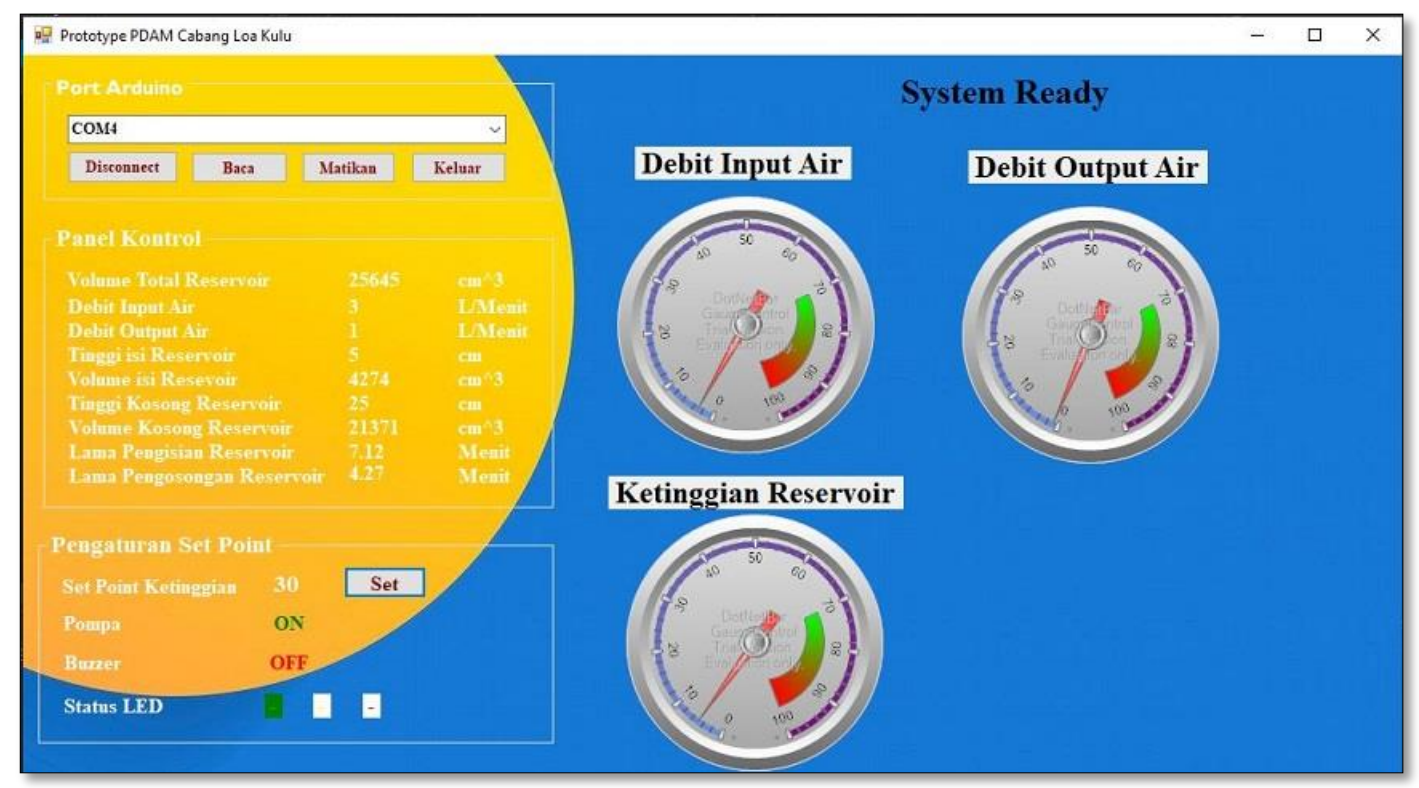

Gambar 5. Tampilan Hasil Pengujian Lama Pengosongan Reservoir pada Jarak $5 \mathrm{~cm}$

\section{Pembahasan}

Berdasarkan dari hasil di atas, pengimplementasian sistem pengaturan pengaturan monitoring ketinggian air pada reservoir menggunakan sensor ultrasonic hc-sr04 dan sensor flowmeter yf-s201 berbasis mikrokontroller arduino uno r3. Dalam pengembangan sistem ini, menerapkan metode prototype di mana memiliki tahapan - tahapan, diantaranya : Mewawancarai secara langsung staf PDAM, Membuat dan memperbaiki prototype, Staf PDAM menguji coba prototype. Tahap - tahap ini berguna untuk menentukan apa saja yang di butuhkan dalam mengembangkan sistem dengan cara mewawancarai langsung ke ke staf PDAM. Selanjutnya merancang sistem dan merakit sistem serta merancang program dan yang terakhir yaitu dilanjutkan dengan pengujian tingkat kelayakan dari sistem dan memperbaikinya. Dari hasil pembuatan sistem diatas mendapatkan hasil bahwa sistem dapat memonitoring ketinggian air di dalam reservoir secara otomatis dan dan mengetahui waktu yang dibutuhkan untuk proses pengisian dan pengosongan reservoir.

Pada penelitian sebelumnya yang telah dilakukan oleh (Alawiah \& Al Tahtawi, 2017) dan (Amin, 2018) sistem yang dibangun hanya sebatas menghidupkan dan mematikan pompa secara otomatis berdasarkan setpoint yang ditetapkan dimana sensor ultrasonic hc-sr04 sebagai sensor untuk mengetahui ketinggian air dan relay sebagai switch untuk menghidupkan dan mematikan pompa tanpa mengetahui waktu yang dibutuhkan untuk proses pengisian dan pengosongannya. Oleh karena itu pada penelitian ini selain menghidupkan dan mematikan pompa secara otomatis berdasarkan setpoint yang ditetapkan penulis juga menambahkan berupa peramalan waktu yang dibutuhkan untuk proses pengisian dan pengosongan reservoir. 
Hasil pengujian diketahui bahwa ketika ketinggian air berada dibawah $10 \mathrm{~cm}$ maka kondisi pompa on, buzzer off, solenoid valve on dan indikator lampu led hijau on. Ketika ketinggian air berada diatas $10 \mathrm{~cm}$ pompa on, buzzer off, solenoid valve on dan indikator lampu led kuning on. Ketika ketinggian air berada diatas $20 \mathrm{~cm}$ pompa on, buzzer off, solenoid valve on dan indikator lampu led merah on. Sedangkan ketika ketinggian air berada diatas $30 \mathrm{~cm}$ pompa off, buzzer on, solenoid valve off dan indikator lampu led merah on. Dengan rata-rata debit input 3,6 liter/menit dan rata-rata debit output 1,06 liter/menit dapat diketahui waktu yang butuhkan untuk proses pengisian reservoir sebesar 2,93 menit, sedangkan waktu yang dibutuhkan untuk proses pengosongan reservoir sebesar 12,10 menit. Hasil pengukuran dari prototype yang dibangun ditampilkan melalui LCD 16 × 2 dan aplikasi visual studio 2019.

\section{SIMPULAN}

Berdasarkan penelitian dan pembahasan implementasi sistem pengaturan pengaturan monitoring ketinggian air pada reservoir menggunakan sensor ultrasonic hc-sr04 dan sensor flowmeter yf-s201 berbasis mikrokontroller arduino uno r3 dapat disimpulkan : Sistem dapat memonitoring ketinggian air di dalam reservoir, Sistem dapat mengetahui waktu yang dibutuhkan untuk proses pengisian reservoir, Sistem dapat mengetahui waktu yang dibutuhkan untuk proses pengosongan reservoir dan Sistem dapat menampilkan hasil pengukuran melalui LCD 16 x 2 dan aplikasi visual studio 2019.

\section{REFERENSI}

Akinwole, O. O. (2020). Design, simulation and implementation of an Arduino microcontroller based automatic water level controller with I2C LCD display. International Journal of Advances in Applied Sciences (IJAAS), 9(2), 77-84. https://doi.org/10.11591/ijaas.v9.i2.pp77-84

Alawiah, A., \& Al Tahtawi, A. R. (2017). Sistem Kendali dan Pemantauan Ketinggian Air pada Tangki Berbasis Sensor Ultrasonik. KOPERTIP:Jurnal Ilmiah Manajemen Informatika Dan Komputer, 01(01), 25-30.

Amarudin, A., Saputra, D. A., \& Rubiyah, R. (2020). Rancang Bangun Alat Pemberi Pakan Ikan Menggunakan Mikrokontroler. Jurnal Ilmiah Mahasiswa Kendali Dan Listrik, 1(1), 7-13. https://doi.org/10.33365/jimel.v1i1.231

Amin, A. (2018). Monitoring Water Level Control Berbasis Arduino Uno Menggunakan LCD LM016L. Jurnal Ilmiah Teknik Elektro, 1(2), 41-52.

Destiarini. (2020). Modifikasi Helm Dengan Menggunakan Wiper Automatic Berbasis Arduino Nano. Jurnal Informanika, 6(2), 70-79.

Gunawan, G., \& Fatimah, T. (2020). Implementasi Sistem Pengaturan Suhu Ruang Server Menggunakan Sensor DHT11 dan Sensor PIR Berbasis Mikrokontroler. Edumatic: Jurnal Pendidikan Informatika, 4(1), 101-110.

Gunawan, I., Akbar, T., \& Giyandhi Ilham, M. (2020). Prototipe Penerapan Internet Of Things (Iot) Pada Monitoring Level Air Tandon Menggunakan Nodemcu Esp8266 Dan Blynk. Infotek: Jurnal Informatika Dan Teknologi, 3(1), 1-7. https://doi.org/10.29408/jit.v3i1.1789

Haiqal, H., Azmeri, A., \& Fatimah, E. (2021). Analisis Kinerja Pelayanan Air Bersih PDAM Tirta Daroy Kota Banda Aceh. Jurnal Arsip Rekayasa Sipil Dan Perencanaan, 3(3), 203210. https://doi.org/10.24815/jarsp.v3i3.16643

Haszerila, W., Hassan, W., Jidin, A. Z., Asma, S., Aziz, C., \& Rahim, N. (2019). Flood disaster indicator of water level monitoring system. International Journal of Electrical and Computer Engineering (IJECE), 9(3), 1694-1699. https://doi.org/10.11591/ijece.v9i3.pp1694-1699

Hidayat, R., Irmayanti, A., \& Tommy, M. (2020). Implementasi Multi Factor Evaluation 
Process untuk Penentuan Tempat Pembuangan Akhir Berbasis Web Aplication. Edumatic: Jurnal Pendidikan Informatika, 4(2), 103-111.

Irvawansyah, \& Azis, R. A. (2018). Prototype Sistem Monitoring dan Pengontrolan Level Tangki Air Berbasis SCADA. Jurnal Teknologi Terapan, 4(1), 27-32.

Michael, D., \& Gustina, D. (2019). Rancang Bangun Prototype Monitoring Kapasitas Air Pada Kolam Ikan Secara Otomatis Dengan Menggunakan Mikrokontroller Arduino. Jurnal IKRA-ITH Informatika, 3(2), 59-66.

Pelawi, S. D. B., \& Manan, S. (2017). Sistem Monitoring Volume Air Menggunakan Sensor Ultrasonik Dan Monitoring Output Volume Air Menggunakan Flow Meter Berbasis Arduino. Gema Teknologi, 19(2), 6-9. https://doi.org/10.14710/gt.v19i2.21863

Saleh, M., \& Haryanti, M. (2017). Rancang Bangun Sistem Keamanan Rumah Menggunakan Relay. Jurnal Teknologi Elektro, UniversitasMercu Buana, 8(2), 87-94.

Saputra, R., Ariyani, P. F., \& Juliasari, N. (2016). Sistem Monitoring Stok Tangki Air Memanfaatkan Sensor Ultrasonik Dan Mikrokontroler Arduino Mega. Jurnal Budi Luhur Informasi Teknologi, 15(1), 1-8.

Setyadi, P., \& Nurcahyo, S. E. (2017). Perhitungan Pressure Drop Sistem Plambing Air Bersih Dengan Menggunakan Media Microsoft Excel Sebagai Database Pada Gedung "X " Jakarta Selatan. Prosiding Seminar Nasional Sains Dan Teknologi FT-Universitas Muhammadiyah Jakarta, 1-12.

Sitohang, E. P., Mamahit, D. J., \& Tulung, N. S. (2018). Rancang Bangun Catu Daya Dc Menggunakan Mikrokontroler Atmega 8535. Jurnal Teknik Elektro Dan Komputer, 7(2), $135-142$.

Suhaeb, S., Abd Djawad, Y., Jaya, H., Ridwansyah, Sabran, \& Risal, A. (2017). Mikrokontroler dan Interface. In Buku Ajar Jurusan Pendidikan Teknik Elektronika UNM. Universitas Negeri Makassar.

Suratmi. (2017). Studi Mengenai Kebutuhan Air Bersih di Wilayah Cakupan Pelayanan PDAM Cabang Loa Kulu Kecamatan Loa Kulu Kabupaten Kutai Kartanegara. Media Sains, $10(1), 82-90$.

Triono, M. O. (2018). Akses Air Bersih Pada Masyarakat Kota Surabaya Serta Dampak Buruknya Akses Air Bersih Terhadap Produktivitas Masyarakat Kota Surabaya. Jurnal Ilmu Ekonomi Terapan, 3(2), 93-106. https://doi.org/10.20473/jiet.v3i2.10072

Zakaria, Fauzi, Irhamni, \& Iswardy, E. (2021). Rancang Bangun Sistem Pengontrolan Lampu Berbasis Komputer dan Arduino untuk Aplikasi Smart Home. Jurnal Komputer, Informasi Teknologi, Dan Elektro, 6(1), 26-31. 